\title{
Indictment by a Grand Jury Exposed to Immune Testimony: The Case for a Per Se Rule
}

Federal courts have often acknowledged the tension between the constitutional privilege against self-incrimination and the state's need to compel testimony in criminal cases through the use of immunity statutes. . The fifth amendment states that "[no] person ... shall be compelled in any criminal case to be a witness against himself."2 On its face this provision allows no exceptions. However, the courts have upheld immunity statutes on the ground that such statutes, properly drafted and administered, have the same ultimate effect as the privilege: ensuring that the witness will not later be convicted on the basis of the compelled testimony. ${ }^{3}$

The federal immunity statute provides that a witness granted immunity in order to compel his testimony at a hearing may not refuse to testify on the basis of his fifth amendment privilege against self-incrimination. In order to protect that privilege, information derived directly or indirectly from the compelled testimony may not be used against the witness in any criminal case. ${ }^{4}$ This type of immunity is usually called "use and derivative use" immunity. ${ }^{5}$ It is different from the broader "transactional immunity,"

${ }^{1}$ See, e.g., Kastigar v. United States, 406 U.S. 441, $444-47$ (1972); Piccirillo v. N.Y., 400 U.S. 548, 562 (1971) (Brennan, J., dissenting); Counselman v. Hitchcock, 142 U.S. 547, 58586 (1892).

2 U.S. Const. amend. V.

${ }^{3}$ See Kastigar, 406 U.S. at 453; Murphy v. Waterfront Comm'n, 378 U.S. 52,79 (1964); Brown v. Walker, 161 U.S. 591, 607-08 (1896). In addition, see notes 21-26 and accompanying text below.

+ 18 U.S.C. $\$ 6002$ (1985). This section reads in relevant part:

Whenever a witness refuses, on the basis of his privilege against self-incrimination, to testify or provide other information in a proceeding before or ancillary to . . . a court or grand jury of the United States, ... . and the person presiding over the proceeding communicates to the witness an order issued under this part, the witness may not refuse to comply with the order on the basis of his privilege against self-incrimination; but no testimony or other information compelled under the order (or any information directly or indirectly derived from such testimony or other information) may be used against the witness in any criminal case. . . .

s It has also been labeled "use-plus-fruits immunity." See, e.g., Note, Standards for Exclusion in Immunity Cases After Kastigar and Zicarelli, 82 Yale L. J. 171, 171 (1972). "Derivative use" occurs most often when the compelled testimony leads the prosecution to new evidence and the prosecution attempts to introduce that evidence against the immune 
which prevents indictment of the immune witness for any transaction disclosed in his testimony. ${ }^{6}$

The federal use and derivative use immunity statute was upheld against a constitutional challenge in Kastigar $v$. United States, ${ }^{7}$ which held that "immunity from use and derivative use is coextensive with the scope of the privilege against self-incrimination, and therefore is sufficient to compel testimony over a claim of the privilege." 8 The Court, aware of the potential for abuse of this testimony, placed a "heavy burden" on the prosecution of proving that evidence was "derived from legitimate independent sources," rather than from the immunized testimony. ${ }^{9}$

The Kastigar standard presents a number of practical problems in implementation, most centering on the difficulty of proving "derivative use." Another question has come to light in a pair of recent court of appeals cases. In United States $v$. Hinton ${ }^{11}$ and United States $v$. Zielezinski, ${ }^{12}$ the defendants were granted use and derivative use immunity. Both defendants were then indicted by the same grand juries that had heard the compelled testimony, and the prosecutor in each case alleged an independent basis for the indictment. ${ }^{13}$ In Hinton, the Second Circuit held that this procedure constituted a breach of "fundamental fairness"14 and disallowed it under the court's supervisory power. ${ }^{15}$ The Ninth Circuit took a different approach in Zielezinski, ordering a hearing

witness in a subsequent criminal proceeding.

- See Brown, 161 U.S. at 607-08 (upholding transactional immunity against fifth amendment challenge).

7406 U.S. 441 (1972).

Id. at 453 . In so holding, the Court explicitly stated that full transactional immunity is much broader than the protection afforded by the fifth amendment. Id.

-Id. at 461-62. The magnitude of this burden is discussed below at notes 77-79 and accompanying text. When the defendant raises a challenge to the prosecution's evidence before trial, the government is given the opportunity to prove an independent source for the evidence at a pretrial hearing, often called a "Kastigar hearing." See notes 82-85 and accompanying text below.

10 For a discussion of these difficulties, see United States v. Dornau, 359 F. Supp. 684, 687 (S.D. N.Y. 1973), rev'd on other grounds, 491 F.2d 473 (2d Cir. 1974). See also Note, 82 Yale L. J. at 181 (cited in note 5); The Supreme Court, 1971 Term, 86 Harv. L. Rev. 1, 187 (1972).

" 543 F.2d 1002 (2d Cir. 1976).

12740 F.2d 727 (9th Cir. 1984).

13 Hinton, 543 F.2d at 1007; Zielezinski, 740 F.2d at 728.

14543 F.2d at 1010.

15 Id. This supervisory power has long been recognized by the courts. See McNabb v. United States, 318 U.S. 332, 340 (1943) ("Judicial supervision of the administration of criminal justice in the federal courts implies the duty of establishing and maintaining civilized standards of procedure and evidence."). The scope of this authority and its use in the present situation are discussed below in notes 86-99 and accompanying text. 
to determine whether the indictment was obtained through use or derivative use of the defendant's immune testimony before the grand jury. ${ }^{16}$

This comment examines the question raised by the Hinton and Zielezinski cases: whether a person granted immunity to testify before a grand jury may then be indicted by that same grand jury when it has a basis for the indictment that is allegedly independent of the compelled testimony. Part I discusses the major cases. Part II analyzes the statutory and constitutional arguments, emphasizing Kastigar and the judicial reluctance to quash indictments on constitutional grounds.

Part III examines possible solutions to the problem. In the first place, the courts could refuse to quash an indictment that has been issued by a grand jury exposed to compelled testimony, on the ground that indictments may only be overturned in cases involving extreme constitutional violations going to the heart of the grand jury process. ${ }^{17}$ However, this comment concludes that the courts should exercise their power to quash indictments. It then turns to three potential procedures for deciding whether or not to quash an indictment. First, a court might examine the evidence on its own. Second, the court might require a pretrial hearing on the issue of whether the indictment has a basis wholly independent of the compelled testimony. ${ }^{18}$ If the court found that such a basis did not exist, the indictment would be quashed. Finally, the courts might adopt the Second Circuit's per se rule as formulated in Hinton, quashing any indictment issued by a grand jury that has been exposed to immunized testimony, on the ground that in such circumstances it is impossible for the prosecution adequately to prove a wholly independent basis for the indictment. ${ }^{19}$ The authority for quashing may be found in the supervisory power of the federal courts. ${ }^{20}$

16740 F.2d at 734 .

17 See note 67 and accompanying text below.

18 This is the approach adopted by the Ninth Circuit in Zielezinski, 740 F.2d at 733-34. See also notes 104-07 and accompanying text below.

19 See Hinton, 543 F.2d at 1010 ("The prospect of peering into the grand jurors' minds, or of examining them individually to ascertain whether Hinton's testimony was improperly used is both impractical and unpalatable."). See also notes 108-12 and accompanying text below. In United States v. Garrett, 797 F.2d 656, 664 (8th Cir. 1986), the Eighth Circuit chose a slightly different approach: it required that an evidentiary hearing be held but allowed the district court to determine whether the government would be unable to meet its burden in such a hearing in a specific case because of the nature of the immunized testimony.

${ }^{20}$ See notes 86-99 and accompanying text below. For general background, see McNabb, 
This comment concludes that the courts should exercise their supervisory power to adopt the third alternative, an absolute rule against indictment by the grand jury exposed to the immune testimony. This approach will, at minimal cost, eliminate a practice that raises serious constitutional problems and will thereby protect the integrity of the judicial system.

\section{Judicial Analysis of the Problem}

\section{A. The Kastigar. Background}

In Kastigar $v$. United States, ${ }^{21}$ the Supreme Court upheld the federal use immunity statute ${ }^{22}$ against constitutional challenge. In Kastigar, a defendant challenged the use of immune testimony as evidence at trial. ${ }^{23}$ The Court's analysis focused on the relationship between immunity statutes and the fifth amendment privilege against self-incrimination. ${ }^{24}$ According to the Court, the privilege "protects against any disclosures that the witness reasonably believes could be used in a criminal prosecution or could lead to

318 U.S. 332.

21406 U.S. 441 (1972).

${ }^{22} 18$ U.S.C. $\$ 6002$ (1985). For many years the Court upheld only "transactional immunity" statutes, which required that the witness not be prosecuted for any transactions discussed in the compelled testimony. See Brown, 161 U.S. at 608. During that period, the Court struck down a "use immunity" statute that did not explicitly prohibit derivative use of the compelled testimony. Counselman, 142 U.S. at 564-65. The Court implied that only a broader immunity statute of the transactional type could satisfy the fifth amendment burden when it asserted that "no statute which leaves the party or witness subject to prosecution after he answers the criminating [sic] question put to him, can have the effect of supplanting the privilege conferred by the Constitution." Id. at 585. This dictum was unchallenged until 1964, when for the first time the Court upheld a statute granting less than full transactional immunity. Murphy, 378 U.S. at 79 (holding that federal prosecutors could not make use of testimony given under a state use and derivative use immunity statute). Partially in response to this narrowing of fifth amendment protection, Congress enacted 18 U.S.C. $\$ 6002$, the use and derivative use immunity statute, which was subsequently upheld in Kastigar. 406 U.S. at 452-53. For a discussion of this series of cases, see id. at $448-53$.

23406 U.S. at 448.

24 See id. at 448-53. Note that at least one Justice once argued that no immunity statute is constitutionally acceptable. Brown, 161 U.S. at 630 (Field, J., dissenting) ("No substitute for the protection contemplated by the amendment would be sufficient were its operation less extensive and efficient [than the amendment itself]."). This argument focuses on the plain language of the amendment, arguing that it allows for no artificial legislative substitutes because no substitute can completely safeguard the bundle of rights protected by the amendment. It is also worth noting Justice Marshall's view (though it has not been accepted) that "because an immunity statute gives constitutional approval to the resulting interrogation, the government is under an obligation here to remove the danger of incrimination completely and absolutely." Kastigar, 406 U.S. at 470 (dissenting opinion). 
other evidence that might be so used."2s The immunity statute must grant protection to the witness that is at least as extensive as the protections granted by the fifth amendment privilege, although it need not go further. ${ }^{26}$

Applying the fifth amendment standard to the federal immunity statute, the Kastigar Court held the statute constitutional because it "prohibits the prosecutorial authorities from using the compelled testimony in any respect."27 Put another way, in order for a use immunity statute to place a witness in the same position as if he had exercised his fifth amendment privilege, the prosecution must be prohibited from using the immunized testimony in any way against him. This requirement is the core of the Kastigar decision.

Two difficulties arise in extending Kastigar's requirements to the situation presented in Hinton and Zielezinski. The first issue is whether Kastigar's holding applies in the grand jury context. In cases like Hinton and Zielezinski, a defendant seeks to quash an indictment altogether-rather than simply exclude pieces of evidence to be used against him at trial-on the ground that the indictment was obtained by use of his immunized testimony. ${ }^{28} \mathrm{Nev}-$ ertheless, this comment concludes that the Kastigar requirement must extend to grand jury situations like those in Hinton and Zielezinski.

The second difficulty in applying Kastigar is whether the procedures suggested by that case for ensuring evidence is derived solely from sources independent of the immunized testimony are appropriate and sufficient to resolve a challenge to an indictment. The first procedural requirement imposed by the Court in the particular situation of Kastigar relates to the government's burden of proof; the second centers on the procedures to be used by lower

2s 406 U.S. at $444-45$ (footnote omitted).

${ }^{28}$ Id. at 453 . This principle runs through many of the cases in this area. Consider, for example, Ullmann v. United States, 350 U.S. 422,439 (1956) ("Immunity displaces the danger [of criminal punishment that is the basis of the privilege]. Once the reason for the privilege ceases, the privilege ceases.").

${ }^{27} 406$ U.S. at 453 (emphasis in original).

${ }^{28}$ For example, see Garrett, 797 F.2d at 658 (defendant indicted by same grand jury that heard his previous testimony); United States v. Byrd, 765 F.2d 1524, 1526 (11th Cir. 1985) (trial court dismissed first indictment against defendant because it was returned by same grand jury that had heard defendant's immunized testimony); United States v. Romano, 583 F.2d 1, 5 (1st Cir. 1978) (upholding indictment based on defendant's proffer of evidence to Senate subcommittee because no immunity had been granted); United States v. Cortese, 568 F. Supp. 119, 130-31 (M.D. Pa. 1983) (a transcript of defendant's immunized testimony before one grand jury was given to another grand jury, which indicted him). 
courts to determine whether the prosecution has met that burden. This comment finds that although the burden should apply in the grand jury context, the Kastigar procedural requirements are inadequate in this situation.

\section{B. The Per Se Rule of Hinton}

In the 1976 case of United States $v$. Hinton, ${ }^{29}$ the defendant testified before a grand jury on three separate days under a grant of immunity, generating approximately 200 pages of testimony. ${ }^{30}$ The same grand jury that heard this testimony later indicted the defendant. Despite numerous requests from defense counsel, the trial court refused to require a hearing on the issue of whether the indictment violated the immunity statute, holding that there was a wholly independent basis for the indictment. ${ }^{31}$

In reversing the defendant's conviction, the Second Circuit determined that it would be "virtually impossible" for the government to prove a wholly independent basis for the indictment when the indicting grand jury had heard the compelled testimony. ${ }^{32}$ Even where the immune testimony consisted of a denial of any role in the illegal transaction, the Court argued, the testimony still might contribute to the indictment: the immune witness's testimony could well act as credibility evidence against him. The jury might compare his testimony and demeanor against that of other witnesses and might be more convinced by the latter. Once the jury discredited the immunized testimony, they could well begin to distrust the immune witness on other matters as also. ${ }^{33}$ If the immune witness had remained silent or had been permitted to assert his fifth amendment privilege, these negative inferences would not have arisen.

The decision in Hinton also emphasized the evidentiary difficulties of discerning whether the grand jury had made any use or derivative use of the immunized testimony in issuing the indictment. ${ }^{34}$ The difficult question of whether the grand jury based its indictment on evidence wholly independent of the compelled testimony could not be answered without "peering into the grand jurors' minds," a task the court found "both impractical and

\footnotetext{
29 543 F.2d 1002 (2d Cir. 1976).

so Id. at 1007.

st Id. at 1007 n.6.

32 Id. at 1007-08.

33 Id. at 1009.

34 Id. at 1010. See also text at notes 106-07 below.
} 
unpalatable." "35

The Second Circuit also asserted that the burden of convening a second "untainted" grand jury was "not so onerous as to justify the jeopardizing of a defendant's Fifth Amendment rights." 36 This solution could be implemented at little expense by presenting the second grand jury with transcripts of the first proceedings, excising the immune testimony. ${ }^{37}$ The court concluded, therefore, that an evidentiary hearing on improper use would not satisfactorily resolve this type of case. ${ }^{38}$ It adopted a per se rule that an indictment by a grand jury that hears the defendant's immunized testimony will be overturned. ${ }^{39}$ Although the court stated that an indictment by such a "tainted" grand jury is "fraught with applicable constitutional problems," it based its holding on an exercise of its supervisory power rather than on the Constitution. ${ }^{40}$ The Hinton decision has been approved in several later cases. ${ }^{41}$

\section{Case by Case Hearings under Zielezinski}

In contrast, the Ninth Circuit in United States v. Zielezinski ${ }^{42}$ refused to adopt the per se rule of Hinton. In Zielezinski, the defendant had been granted immunity under the federal immunity statute in return for testimony about a series of drug transactions. Although he denied involvement in a cocaine sale, his testimony was contradicted by other witnesses. ${ }^{43}$ The trial court denied a mo-

ss 543 F.2d at 1010.

36 Id.

${ }^{37}$ This alternative might be less economically feasible, of course, in small or rural jurisdictions with only one grand jury sitting at any time. This narrow situation does not, however, justify rejection of the Hinton rule if that rule is otherwise sound.

${ }^{38} 543$ F.2d at 1010.

39 Id.

${ }^{10}$ Id. This reliance on the supervisory power may have been based at least in part on doubt as to the force of constitutional protections in a grand jury proceeding. See notes $63-$ 68 and accompanying text below. The court never discussed the reasons behind its rejection of a purely constitutional basis for the holding.

1 See, e.g., United States v. Anzalone, 555 F.2d 317, 319 (2d Cir. 1977). The Seventh Circuit has indicated in dicta that it would follow Hinton under similar facts. In re Perlin, 589 F.2d 260, 269 (7th Cir. 1978). Compare Cortese, 568 F. Supp. at 130-32 (quashing indictment where transcript of immune testimony presented to second grand jury, which indicted defendant).

In Byrd, 765 F.2d at 1524, the trial court dismissed an indictment because it was returned by the same grand jury that had heard the defendant's immune testimony. Id. at 1526. Interestingly, the government did not oppose the order to dismiss. Instead, it submitted the independent evidence to a second grand jury. The second indictment was upheld on appeal. Id. at 1529 .

22740 F.2d 727 (9th Cir. 1984).

43 Id. at 728. This situation is similar to that discussed by the Second Circuit in 
tion to overturn the indictment without holding a hearing on the matter. ${ }^{44}$ The Ninth Circuit reversed and remanded for a hearing to determine whether there was a basis for the indictment independent of the immunized testimony. ${ }^{45}$

The Ninth Circuit rejected the Hinton rule, both as a constitutional requirement and as an exercise of its supervisory power. ${ }^{46}$ Although acknowledging that indictment by the same grand jury that heard the compelled testimony "threaten[s] the very integrity of the grand jury itself," and that "[i]f an indictment is tainted, the Constitution requires that it be quashed,"47 the court concluded that "relatively few constitutional challenges to indictments can be raised." ${ }^{\prime 48}$ Because the Hinton rule did not rest on a constitutional foundation, the Ninth Circuit did not consider itself constitutionally obligated to adopt the rule. ${ }^{49}$

Instead, the court invoked its supervisory power to require a hearing on the issue of improper use, ${ }^{30}$ reasoning that this requirement would effectively deter governmental misconduct ${ }^{51}$ and would be sufficient to "protect the integrity of the judicial process"52 by bringing to light improper use of compelled immunized testimony. The court held that at the hearing, the prosecution must disprove improper use by a preponderance of the evidence. ${ }^{53}$

Hinton. See 543 F.2d at 1009 . See also text preceding note 33. The Ninth Circuit did not address the argument that placing the defendant on the witness stand allows the grand jury to judge his credibility even if he denies any criminal wrongdoing.

14740 F.2d at 728-29.

is Id. On remand, the district court found that the indictment decision was not influenced by the immune testimony, a finding that was upheld on appeal as not clearly erroneous. United States v. Zielezinski, 756 F.2d 1448 (9th Cir. 1985).

16 740 F.2d at 729 .

4 Id. at 731.

18 Id. The court relied here on Costello v. United States, 350 U.S. 359 (1956); United States v. Blue, 384 U.S. 251 (1966); and United States v. Calandra, 414 U.S. 338 (1974). These cases, limiting the power of courts to quash grand jury indictments, are discussed below at notes 64-74 and accompanying text.

14740 F.2d at 729 .

so Id. In requiring this hearing, the court stated: "Only a hearing can convincingly establish that the command of the Fifth Amendment has been satisfied." Id. at 734. If this is so, then one might argue that a hearing is constitutionally required. In the more recent case of Garrett, 797 F.2d at 664, the court followed the Ninth Circuit and ordered a hearing in the same situation. The procedure endorsed by the Eighth Circuit, however, differs from that approved by the Ninth Circuit: Garrett would allow a court to overturn an indictment without a hearing in cases where it would be impossible for the prosecution to meet its "heavy burden." Id. at 663-64.

s1 740 F.2d at 733 . Given the evidentiary difficulties presented by such a hearing, discussed below at notes 106-07 and accompanying text, this contention is questionable.

32740 F.2d at 733 .

s3 Id. at 734. 
The Zielezinski court also recognized that the entire problem could and should have been avoided by prohibiting indictment by the same grand jury that had heard the immune testimony. ${ }^{54}$ To this extent, the Court agreed with the Second and Eighth Circuits. The only point of disagreement between the circuits is the choice of procedures for protecting defendants' rights while minimizing the burden on the legal system.

\section{Rights of the IMmUne Witness}

As noted in part I, Hinton and Zielezinski are not typical use immunity cases. Most use immunity cases, like Kastigar itself, involve a challenge to the use of the evidence by the prosecutor at trial $; 5$ in contrast, the cases here concern the use of the immune testimony by the grand jury in issuing an indictment.

This difference has important implications for the scope of the protections afforded the accused by the immunity statute and the Constitution when there is a tainted indictment. First, although the fifth amendment undoubtedly applies in the grand jury context, ${ }^{56}$ the rights it guarantees the accused may not be as extensive in grand jury proceedings as at trials. The Supreme Court has been reluctant to overturn indictments in most cases, ${ }^{57}$ perhaps because it believes that the cost of quashing an indictment exceeds the cost of suppressing tainted evidence at trial.

Second, the factual distinction between tainted indictment cases and Kastigar may counsel against the application of Kastigar's procedural requirements in cases like Hinton and Zielezinski. Because the issues are different in the latter cases, the procedures best suited to resolve those issues might likewise differ. In particular, the Kastigar hearing may prove inadequate to the difficult task of probing grand jurors' minds to determine the bases they relied on in indicting.

To resolve these issues, this section of the comment first examines the federal use immunity statute for guidance. However,

54 Id. ("Prosecutors should avoid permitting grand juries to indict witnesses who have testified before them under grants of immunity."). Also consider Hinton, 543 F.2d at 1010 ("convening a grand jury distinct from that which heard the immunized testimony is not so onerous as to justify the jeopardizing of a defendant's Fifth Amendment rights").

${ }^{s}$ See note 28 and accompanying text above.

so Yale Kamisar, Wayne R. LaFave, and Jerold H. Israel, Modern Criminal Procedure 749 (5th ed. 1980) ("It has long been established that the Fifth Amendment privilege against self-incrimination applies to grand jury proceedings."). For further discussion, see notes 58-62 and accompanying text below.

${ }^{37}$ See notes 63-68 and accompanying text below. 
because the statute itself is of little assistance, the comment turns to the case law. Analysis of the case law shows that quashing an indictment is not necessarily a constitutional requirement, and that the situation in Hinton and Zielezinski is sufficiently different from that in Kastigar to render Kastigar's procedural requirements inappropriate for the resolution of tainted indictment cases.

\section{A. The Immunity Statute}

The federal use immunity statute is broadly drafted, leaving much room for judicial interpretation. It states that "no testimony . . . compelled under the order . . . may be used against the witness in any criminal case. . . ." The statute's application to "any criminal case" echoes the language of the fifth amendment privilege against self-incrimination. ${ }^{59}$ Although it is conceivable that the words "any criminal case" might be interpreted narrowly to afford protection only at trial, the courts have uniformly concluded that "any criminal case" includes the grand jury context for purposes of the fifth amendment privilege. ${ }^{60}$ Thus, the defendant may legitimately raise the question of whether immunized testimony was used to obtain the indictment. ${ }^{61}$

In addition, as the Seventh Circuit has persuasively argued, the "legislative history [of the statute] evinces a clear intent to restrict the scope of immunity authorized by the statute to that which is constitutionally required." ${ }^{2}$ The statutory protection is therefore intended to be exactly coextensive with the guarantees of the fifth amendment. The statute itself thus provides no independent guidance. In order to understand the statute's boundaries, one must turn to the scope of the fifth amendment privilege and

ss 18 U.S.C. $\S 6002$.

so U.S. Const. amend. V.

6 See Counselman, 142 U.S. at 562. See also United States v. Mandujano, 425 U.S. 564, 572 (1976); Hoffman v. United States, 341 U.S. 479, 486 (1951) ("The privilege afforded not only extends to answers that would in themselves support a conviction under a federal criminal statute but likewise embraces those which would furnish a link in the chain of evidence needed to prosecute the claimant for a federal crime."); Kamisar et al., Criminal Procedure at 749 (cited in note 56).

-1 This construction has been accepted by nearly every court ruling on this issue. See, e.g., Hinton, 543 F.2d at 1008 (applying Kastigar in indictment challenge case); Zielezinski, 740 F.2d at 734 (same). For the opposing approach, consider United States v. Henderson, 406 F. Supp. 417, 421-22 (D. Del. 1975) (rejecting applicability of Kastigar to grand jury situation while acknowledging criticism of that position).

${ }^{62}$ In re Daley, 549 F.2d 469, 477 (7th Cir. 1977) (citing Report of the Comm. on the Judiciary on the Organized Crime Control Act of 1970, H.R. Rep. No. 1549, 91st Cong., 2d Sess. 42 (1970); 1970 U.S. Code Cong. and Admin. News 4007, 4017; and 2 National Comm'n on Reform of the Fed. Crim. Laws, Working Papers 1412 (1970)). 
the remedies for its violation.

\section{B. Fifth Amendment Challenge to an Indictment}

The Ninth Circuit in Zielezinski refused to adopt the Hinton rule as a constitutional requirement, arguing that "relatively few constitutional challenges to indictments can be raised." ${ }^{3}$ This argument grows out of a line of Supreme Court cases suggesting that even though the fifth amendment has force in the grand jury context, the remedy for violation of the privilege against self-incrimination in the indictment process may be limited.

The remedial issue is whether an indictment can ever be quashed on fifth amendment grounds. If the fifth amendment is never an appropriate basis to quash an indictment, then any procedure adopted in response to the tainted indictment cases may be imposed, if at all, only as an exercise of the court's supervisory power. If, on the other hand, an indictment may be challenged under the fifth amendment in some instances, then any rule imposed in tainted indictment cases should be analyzed on the basis of its faithfulness to constitutional limitations.

Current case law indicates that the courts' ability to overturn an indictment on purely constitutional grounds is limited and that therefore they may be forced to rely on their supervisory powers to quash an indictment. In a series of cases beginning with Costello $v$. United States, ${ }^{64}$ the Supreme Court has curtailed the power to quash grand jury indictments that are based on evidence allegedly obtained in violation of the privilege against self-incrimination. ${ }^{65}$ In particular, the Court generally has upheld indictments when the evidentiary improprieties occurred outside the grand jury process.

os 740 F.2d at 729. This may also be the unspoken reason for the Hinton court's decision to rely on its supervisory power, rather than on Kastigar and the fifth amendment, as the basis for its ruling.

os 350 U.S. 359 (1956).

so See Costello, 350 U.S. 359 (indictment based on hearsay evidence); Lawn v. United States, 355 U.S. 339 (1958) (use of documents from prior grand jury investigation that were obtained from defendants without warning them against self-incrimination); Blue, 384 U.S. at 251 (criminal indictment based on defendant's Tax Court filings in civil case); Calandra, 414 U.S. at 345 (seizure of records of loansharking activity in course of search for evidence of bookmaking) ("[A]n indictment valid on its face is not subject to challenge on the ground that the grand jury acted on the basis of . . information obtained in violation of a defendant's Fifth Amendment privilege against self-incrimination."). See also Peter Arenella, Reforming the Federal Grand Jury and the State Preliminary Hearing to Prevent Conviction Without Adjudication, 78 Mich. L. Rev. 463, 488 (1980) (case law even before Costello "reveals a decided reluctance to dismiss indictments as long as some competent evidence was presented to the grand jury") (footnote omitted). This article also presents an excellent critical analysis of Costello and its progeny. Id. at 487-98. 
For example, the fourth amendment exclusionary rule, which prevents introduction at trial of evidence obtained by an unconstitutional search or seizure, does not apply in a grand jury proceeding, because the search or seizure is separate from that proceeding. ${ }^{66}$ The use of such evidence thus does not corrupt the integrity of the tribunal. On the other hand, one court has indicated that indictments may be dismissed in "flagrant cases" in which "the prosecutor's conduct significantly infringed upon the ability of the grand jury to exercise its independent judgment." 67

In deciding that indictments generally may not be quashed on constitutional grounds, the Court has drawn an analogy to the information drawn by a prosecutor in a case without a grand jury: since a prosecutor may indict on the basis of unconstitutionally obtained evidence, the grand jury should be able to do so as well. ${ }^{68}$

The reasoning of the Court in the line of cases starting with Costello is not persuasive. First, these cases do not concern improprieties within the grand jury process itself. At least two courts have stated that those cases do not prohibit dismissal of an indictment where the grand jury process itself violates the rights of the accused. ${ }^{69}$ In United States $v$. Garrett, the Eighth Circuit held that Costello and its progeny do not preclude "the power of a court to dismiss an indictment where there is a strong likelihood that the grand jury process itself violated the witness's fifth amendment privilege."

The Court's analogy between an indictment by a grand jury and information drawn by a prosecutor is also unpersuasive because the grand jury system is a constitutional requirement.. ${ }^{71}$ The requirement of grand jury indictment in all prosecutions for "capi-

${ }^{68}$ See, e.g., Calandra, 414 U.S. at 338; Costello, 350 U.S. at 359.

67 United States v. Sears, Roebuck \& Co., 719 F.2d 1386, 1391-92 (9th Cir. 1983).

os See, e.g., Lawn, 355 U.S. at 349 ("[T]his Court has several times ruled that an indictment returned by a legally constituted nonbiased grand jury, like an information drawn by a prosecutor, if valid on its face, is enough to call for a trial of the charge on the merits and satisfies the requirements of the Fifth Amendment.").

60 Garrett, 797 F.2d at 661; Zielezinski, 740 F.2d at 732 \& n.3.

${ }^{70}$ Garrett, 797 F.2d at 661 . See also Zielezinski, 740 F.2d at 732 (Costello leaves open the possibility of hearing challenges to indictments where improprieties occurred within the grand jury process).

${ }^{71}$ U.S. Const. amend. V states: "No person shall be held to answer for a capital, or otherwise infamous crime, unless on a presentment or indictment of a Grand Jury. . .." The grand jury was considered by the framers to be "an institution central to the protection of our basic liberties." United States v. Al Mudarris, 695 F.2d 1182, 1185 (9th Cir. 1983). To allow any action to cast doubt upon the independence and integrity of the grand jury is impermissible. See id. ("The prosecutor may not circumvent this safeguard by overreaching conduct that deprives the grand jury of autonomous and unbiased judgment."). 
tal, or otherwise infamous" crimes was designed precisely to protect individual liberties from arbitrary government authority, by ensuring that such serious prosecutions could not be commenced without deliberation by a body drawn from the community. ${ }^{72}$ The Court's analogy ignores this central purpose and the constitutional status of the grand jury proceeding, which render it of a very different nature from the largely discretionary decisions of prosecutors whether to indict in other cases.

Some Justices have presented other reasons for the Court's reluctance to overturn indictments. They have asserted that the grand jury proceeding is not one "in which the guilt or innocence of a defendant is determined, but merely one to decide whether there is a prima facie case against [the defendant]. Any possible prejudice to the defendant ... thus disappears when a constitutionally valid trial jury later finds him guilty beyond a reasonable doubt."73

This position does not, however, explain why the fifth amendment has been held applicable at all in grand jury proceedings despite the lack of finality of the grand jury's decision. In fact, the reason why the privilege extends to grand jury proceedings is clear: indictment can impose substantial prejudice on the defendant. Indictment at the very least forces him to the possible expense of a trial. It may damage his reputation and economic position. Rather than face the expense and risks of a trial, many defendants choose to plea bargain. It is simply unrealistic to assert that the indictment itself can do no lasting damage to a defendant.

Perhaps the Court is unwilling to overturn an indictment because such a remedy can be costly. When an indictment is quashed, a new grand jury must be empaneled and a new proceeding undertaken. The Court may be reluctant to impose these costs as a matter of constitutional principle. But the social costs of excluding evidence at trial, in the Kastigar situation, can be substantial too: suppression may mean an outright dismissal rather than simply the expense of a new grand jury process. Such costs may not be directly economic, but they cannot be ignored. ${ }^{74}$ At any

${ }^{72}$ For historical development, see Kamisar et al., Criminal Procedure at 694-95 (cited in note 56 ).

${ }^{73}$ Rose v. Mitchell, 443 U.S. 545, 575 (1979) (Justice Stewart, concurring, joined by Justice Rehnquist) (footnote omitted).

${ }^{74}$ Nor have they been ignored: consider, for example, the Court's recent expressions of skepticism as to the cost-effectiveness of the fourth amendment exclusionary rule. See, e.g., United States v. Leon, 468 U.S. 897 (1984) ("The substantial social costs exacted by the exclusionary rule for the vindication of Fourth Amendment rights have long been a source 
rate, the protection of constitutional rights is very expensive in many situations, and this seems an odd ground in the first place on which to limit the scope of constitutional requirements.

Thus, the Court's reluctance to overturn indictments rests largely on unsound assumptions. A powerful argument can be made that there should be no general rule against quashing indictments on constitutional grounds. And even if one accepts the notion that a grand jury proceeding should not be overturned because of improprieties external to it, this cannot justify upholding the tainted indictments at issue here, since the impropriety (use of immunized testimony) occurs in the grand jury proceeding itself.

\section{Kastigar and the Fifth Amendment}

Nevertheless, the Court may persist in its reluctance to quash indictments even in tainted-indictment cases like Hinton and Zielezinski. The question thus becomes whether the immunity statute and the fifth amendment, as construed in Kastigar, require any other procedures, and if so, whether those procedural requirements are applicable in the situation where the grand jury that hears immunized testimony later returns an indictment.

It is clear that the fifth amendment analysis of Kastigar requires some procedure for ensuring that immunized testimony is not used as a basis for an indictment. In Kastigar, the Court defined the constitutional limitations on the use and derivative use immunity statute: the compelled testimony could not be used "in any respect."75 Since the fifth amendment applies to grand jury proceedings, if the amendment prohibits use of compelled testimony as evidence at trial, it likewise must prohibit its use in a grand jury proceeding. ${ }^{76}$ However, it does not clearly follow that the courts are constitutionally required to adopt the procedural solution mandated for the particular situation in Kastigar.

In Kastigar, the Court held that the prosecution must meet a "heavy burden" of affirmatively proving that it used sources independent from the immunized testimony to obtain an indictment from the grand jury. ${ }^{77}$ The government's burden "is not limited to

of concern.").

${ }^{75}$ See Kastigar, 406 U.S. at 453 (Court's emphasis). See also text at note 27 above.

76 See Kastigar, 406 U.S. at 461 (testimony inadmissible at trial); cases cited in note 61 above.

77406 U.S. at 461-62. The Court also stressed that the government must show that "all of the evidence it proposes to use was derived from legitimate independent sources." Id. at 461-62 (emphasis supplied) (footnote omitted). For a similar point, see Garrett, 797 F.2d at 664. 
a negation of taint; rather, it imposes on the prosecution the affirmative duty to prove that the evidence it proposes to use is derived from a legitimate source wholly independent of the compelled testimony." "The burden imposed is "heavy" because of the practical difficulties of establishing reliance on a wholly-independent basis for the indictment. ${ }^{79}$

Affirmative proof of independent sources should also be required in cases like Hinton and Zielezinski. The Kastigar Court implicitly viewed such proof as a constitutional requirement. ${ }^{80}$ Moreover, as several courts of appeals have reasoned since, the same positive, practical benefits of the requirement of affirmative proof evident in the typical Kastigar case would also operate in the grand jury context: the requirement of affirmative proof would deter prosecutorial misuse of compelled testimony, furthering the underlying purposes of the fifth amendment and the immunity statute. $^{81}$

However, Kastigar does not mandate specific procedures to prove an independent basis for indictment. In the absence of specific guidance, the trial courts have subsequently established some procedures extrapolated from the Kastigar ruling, such as a pretrial hearing, to determine whether the prosecution can establish a sufficient basis for the indictment wholly independent of the immunized testimony. ${ }^{82}$ In general, these hearings have involved affidavits and live testimony from prosecuting officials and witnesses who testified before the grand jury. ${ }^{83}$ In some cases, courts have

78 Kastigar, 406 U.S. at 460.

70 Some courts have treated the "heavy burden" language of Kastigar as stating an evidentiary requirement and have required the prosecution to prove an independent source by a preponderance of the evidence. See Zielezinski, 740 F.2d at 734. The Kastigar Court, however, concentrated on specifying what facts must be proved, rather than the degree of certainty to which they must be proved.

so A chief reason the immunity statute was upheld against constitutional challenge in Kastigar was that it placed the burden on the government to show an independent basis for the indictment. 406 U.S. at $460-62$.

s1 See Zielezinski, 740 F.2d at 734; Hinton, 543 F.2d at 1009; Garrett, 797 F.2d at 66465. Compare Henderson, 406 F. Supp. at 422 (holding Kastigar hearing unnecessary when defendant challenged indictment, because of reluctance to quash indictments, but acknowledging strong criticism of its position).

s2 See, e.g., Byrd, 765 F.2d at 1526; Romano, 583 F.2d at 3; United States v. Kurzer, 534 F.2d 511, 514 (2d Cir. 1976); United States v. Bianco, 534 F.2d 501, 509 (2d Cir. 1976); United States v. First Western State Bank of Minot, N.D., 491 F.2d 780, 784 (8th Cir. 1974); Dornau, 359 F. Supp. at 685 . On the other hand, in Garrett, 797 F.2d at 659 , Zielezinski, 740 F.2d at 728-29, and Hinton, 543 F.2d at 1007 , the trial courts held no evidentiary hearings on this issue before the cases were appealed.

${ }^{\text {s3 }}$ See, e.g., Byrd, 765 F.2d at 1526-27; First Western State Bank of Minot, 491 F.2d at 784-85. 
undertaken in camera review of the transcripts of the grand jury proceedings, although at times this remedy is disallowed on the ground that it is inconsistent with the adversary nature of the hearing because it discloses the evidence before trial. ${ }^{84}$ In other cases, courts have held that either mere presentation of affidavits or review of the grand jury transcript alone would be sufficient to prove an independent source. ${ }^{88}$ The following section of the comment will assess the merits of the Kastigar hearing and of other procedural requirements in the special context of cases like Hinton and Zielezinski.

While the objective of the court in both the Kastigar situation and the tainted indictment context is the same-finding affirmative proof of an independent source for either an indictment or trial evidence-the most effective procedures to obtain such proof may not be the same in each context. The "Kastigar hearing," which was designed for cases involving challenges to the introduction of the evidence at trial, may not readily transfer to situations where an indictment is challenged, since such a challenge questions the use of the testimony by the grand jury.

\section{Procedural Safeguards}

This comment will examine three possible solutions to the problem posed by Hinton and Zielezinski: a case by case determination by the court alone, a case by case hearing requirement, and a per se rule overturning indictments under these circumstances.

However, the necessary threshold question in evaluating these potential solutions is whether the courts have any authority is the first place to quash indictments under one of the procedures above-that is, either on a case by case finding that the grand jury used the compelled testimony in indicting, or by a per se rule overturning all indictments returned by the grand jury that heard the compelled testimony. The question is whether imposing any procedure is justified under either the Constitution or the courts' supervisory power.

The courts of appeals in Hinton, ${ }^{86}$ Zielezinski, $^{87}$ and United

34 For a discussion of this issue, see Byrd, 765 F.2d at 1532-34. The court in Byrd ultimately held in favor of in camera review. Id. at 1533.

ss For a detailed example of one such review in a slightly different context, see United States v. Thanasouras, 368 F. Supp. 534, 536-37 (N.D. Ill. 1973) (indictment by second grand jury upheld solely on basis of transcript of first grand jury hearing).

${ }^{86}$ See 543 F.2d at 1010.

${ }^{37}$ See 740 F.2d at 733-34. 
States $v$. Garrett ${ }^{88}$ invoked the supervisory power to impose procedural requirements that may not have been constitutionally mandated. The courts' refusal to rely on the Constitution in imposing these requirements was understandable in light of the Supreme Court's reluctance, expressed in the Costello line of cases, to create an expansive constitutional right to quash indictments, ${ }^{89}$ and in light of Kastigar's failure to specify any particular procedures as constitutionally required for the determination of whether there existed an independent source of evidence. These decisions suggest that the Court, if confronted with the question, might not invoke the Constitution in order to resolve the procedural difficulties posed by cases like Hinton and Zielezinski, even though the situation is fraught with constitutional problems. Therefore, if a solution that permits the quashing of indictments can be imposed at all, it may have to be under the supervisory power of the federal courts.

The supervisory power is generally invoked, even if neither the Constitution nor the statute compels such action, when it will effectuate one or more of the following three purposes: ${ }^{90}$ to "implement a remedy for violation of recognized.rights"; ${ }^{21}$ to protect judicial integrity by prohibiting practices which undermine the public image of the courts; ${ }^{22}$ and to "deter illegal conduct." Constitution does not compel the use of the supervisory authority to impose a particular remedy, the remedy chosen by the courts may be materially influenced by the nature of the underlying constitutional requirements. In Zielezinski, the court stated that "[c]onstitutional requirements can often guide us in the exercise of our supervisory powers." Thus, the constitutional prohibition against any use of immune testimony may influence the courts to exercise their supervisory power to quash indictments in cases like Hinton and Zielezinski even though that remedy is not constitutionally required. ${ }^{95}$

${ }^{88}$ See 797 F.2d at 664 .

${ }^{89}$ See notes $63-68$ and accompanying text above.

${ }^{90}$ See United States v. Hasting, 461 U.S. 499, 505 (1983). Compare McNabb, 318 U.S. at $340-41,345$. For a criticism of the supervisory power, see the dissenting opinion of Justice Reed in McNabb, 318 U.S. at 349 ("I am opposed to broadening the possibilities of defendants escaping punishment by these more rigorous technical requirements in the administration of justice.").

${ }^{91}$ Hasting, 461 U.S. at 505 (citation omitted).

92 Id. (citation omitted).

${ }^{93}$ Id. (citation omitted).

94 740 F.2d at 730 (citation omitted).

9s See id. However, if the Constitution actually compels a particular rule, courts should 
The exercise of the supervisory power is appropriate in cases like Hinton and Zielezinski because it will further each of the three purposes of the power. ${ }^{96}$ First, indictment by a tainted grand jury violates constitutional rights and thus requires a remedy. Both the right to an untainted grand jury proceeding and the fifth amendment privilege against self-incrimination are implicated by the practice of allowing an indictment by the grand jury that was exposed to the defendant's immunized testimony. In a close case, where it is questionable whether the prosecution can prove the prima facie case necessary to obtain an indictment, the immunized witness's testimony and demeanor before the grand jury may improperly tip the scales against him.

Second, the integrity of the judicial system is threatened by this indictment procedure. Even if the prosecutor's motives are pure, the perception of impropriety is unavoidable. ${ }^{97}$ Finally, exercise of the supervisory power in these cases will help to deter prosecutorial misconduct.98 A prosecutor will be unlikely to seek indictment by the same grand jury that heard a defendant's immunized testimony if she knows that a court will later quash this indictment under its supervisory power.

It might be argued that when the courts involve themselves in quashing indictments, they become indirectly involved in prosecutorial decisions and thereby undermine the separation of powers. ${ }^{99}$ The force of this argument depends on whether the grand jury is properly conceived of as wholly an arm of the executive branch or as an entity somehow straddling the executive and judicial branches. To the extent that fifth amendment guarantees apply in the grand jury context, the courts must become involved in this proceeding in order to review it for adherence to constitutional commands: the grand jury proceeding looks more like a judicial proceeding. More fundamentally, the grand jury acts as an in-

not impose that rule under the guise of their supervisory authority; if they do, subsequent courts may also disregard constitutional demands because those demands are couched in terms of the more permissive supervisory power.

${ }^{8}$ See Garrett, 797 F.2d at 664-65.

${ }^{97}$ The courts in both Hinton and Zielezinski recognized this problem. See Hinton, 543 F.2d at 1010; Zielezinski, 740 F.2d at 733-34.

${ }^{88}$ See Garrett, 797 F.2d at 664; Zielezinski, 740 F.2d at 733.

90 See United States v. Chanen, 549 F.2d 1306, 1313 (9th Cir. 1977): "[G]iven the constitutionally-based independence of the three actors-court, prosecutor and grand jury-we believe a court may not exercise its 'supervisory power' in a way which encroaches on the prerogatives of the other two unless there is a clear basis in fact and law for doing so." The Chanen decision involved judicial involvement in prosecutorial decisions regarding evidentiary matters. 
dependent check on prosecutorial decisions in order to guard individual rights, and so it cannot be seen as simply an appendage of the prosecutor's office. Since the prosecutor is not free to continue a prosecution after a grand jury's refusal to indict a particular defendant (as she is free to halt the prosecution even if the grand jury returns an indictment), the grand jury cannot properly be deemed simply an arm of the executive. If remedying a tainted grand jury proceeding interferes with prosecutorial decision making, that is a choice the framers of the fifth amendment made when they imposed the grand jury requirement. Thus, the argument based on the separation of powers is not sufficiently persuasive to preclude the courts from exercising their supervisory powers in order to quash indictments.

Assuming the courts have authority to impose procedural requirements, the question then turns to which procedures would be best. The cases have proposed three procedures for resolving the problem posed by Hinton and Zielezinski. The first, used by the trial courts in both of those cases, ${ }^{100}$ involves no hearing: the court, on its own, resolves the issue of whether the indictment is derived from the compelled testimony. The second possible solution is to hold a hearing on the issue, resolving only the clearest cases on the basis of affidavits and transcripts of the grand jury proceeding. This was the path required by the appellate courts in Zielezinski and Garrett under their supervisory power. ${ }^{101}$ Finally, as in Hinton, the court might fashion a per se rule that no indictment handed down by the grand jury hearing the compelled testimony can stand. ${ }^{102}$

The approach taken by the trial courts in Garrett, Hinton, and Zielezinski-upholding the indictments with no hearing-was appropriately rejected by the appellate courts in all three cases. The difficulty with the procedure of having the court review the issue on its own is that if it decides to uphold the indictment, the constitutional challenge will have been dismissed without a hearing. The practice of allowing indictments by the same grand jury that heard the defendant's immunized testimony is so "fraught with applicable constitutional problems"103 that it demands at least a hearing. To allow such indictments to stand without a hearing is also to condone and invite serious prosecutorial misconduct.

100 See Zielezinski, 740 F.2d at 728-29; Hinton, 543 F.2d at 1007.

101 Zielezinski, 740 F.2d at 734; Garrett, 797 F.2d at 663-64.

102543 F.2d at 1010.

103 Id. 
The final question is whether Hinton's per se rule or Zielezinski's hearing requirement is the best procedural solution to the problem posed by these cases. At first sight, the hearing requirement of Garrett and Zielezinski appears to present some advantages over the Hinton rule. Unlike a uniform rule, the hearing requirement allows for a case by case determination on the issue of improper use that would address the concerns, expressed in the Costello line of cases, underlying the judicial reluctance to quash indictments. ${ }^{104}$ In addition, the hearing requirement is more firmly grounded in the Supreme Court's decisions on the use immunity statute, since the hearing requirement is indirectly derived from the Court's decision in Kastigar. ${ }^{105}$

However, Zielezinski's reliance on Kastigar seems misplaced. The traditional Kastigar hearing involves proof of an independent foundation for evidence to be introduced at trial, whereas the hearing in a case like Zielezinski must focus on proof that the grand jury relied on testimony that was independent of the immunized testimony as the basis for its indictment. In a tainted indictment case, the hearing concentrates only tangentially on the prosecutor, since the defendant objects primarily to the grand jury's reliance on the immune testimony in its decision to indict. ${ }^{108}$ The hearing in such cases involves the difficult examination of the reasoning used by the grand jury, as compared to the relatively simple assessment at a Kastigar hearing of the prosecutor's use of the immunized testimony. The Kastigar hearing is virtually worthless in ferreting out a grand jury's improper use of compelled testimony. Because of the evidentiary difficulties, the standard is virtually useless. The government will find it practically impossible to show the jury did not rely on the compelled testimony in returning the indictment, and if the government did make such a showing the defense would find it practically impossible to rebut. ${ }^{107}$

${ }^{204}$ See notes 63-74 and accompanying text above.

${ }^{105}$ See notes $82-84$ and accompanying text above.

${ }^{108}$ See Kastigar, 406 U.S. at 469 (Marshall, J., dissenting); Piccirillo, 400 U.S. at 568 (Brennan, J., dissenting). In addition, consider Gerald Gunther, Foreword: In Search of Evolving Doctrine on a Changing Court: A Model for a Newer Equal Protection, 86 Harv. L. Rev. 1, 187 (1972); Note, 82 Yale L. J. at 181 (cited in note 5). For a contrary position, see Murphy, 378 U.S. at 102-04 (White, J., concurring).

For a more detailed discussion of the evidentiary difficulties of "peering into" the mind of each grand jury member, see text at notes 34-35 above, discussing Hinton's argument that such a process is "both impractical and unpalatable." $543 \mathrm{~F} .2 \mathrm{~d}$ at 1010.

${ }^{107}$ In the typical Kastigar case, the prosecution holds almost all the evidence, making it difficult for the defendant to defeat the prosecution's showing of an independent basis. The evidentiary difficulties in Hinton-Zielezinski cases simply exacerbate this problem. See 
In contrast to these fruitless and costly inquiries, the Hinton rule, which forbids indictment by a grand jury exposed to immunized testimony, will help to ensure protection of the witness's fundamental rights and will minimize the cost to society. ${ }^{108}$ The prosecution can simply submit the transcripts of the first grand jury proceedings to a second grand jury, excising the immunized testimony. While this approach does not ensure that the prosecuting authorities will not utilize the compelled testimony in order to obtain evidence for the second grand jury, it does guarantee that the grand jury will not rely directly on the immunized testimony as the basis for an indictment. ${ }^{109}$ Once the rule is announced, prosecutors will be able to modify their conduct to avoid quashing of indictments.

Of course, as a corollary to the Hinton rule, failure to convene a second, untainted grand jury would result in a mandatory quashing of the indictment. Since the burden of proof in the Zielezinski hearing is "virtually impossible"110 to meet, the courts' decisions in both Zielezinski and Hinton would result in a quashing of the indictment in most cases. The advantage of Hinton, however, is not that it necessarily achieves a improved result, but that it will achieve the same result as Zielezinski at a decreased cost to the system and with increased certainty for the defendant. It also reduces the number of cases in which that result is necessary by modifying prosecutorial conduct ex ante. Therefore, because the courts can minimize the negative effect of compelled testimony for the defendant while leaving open the possibility of indictments based upon untainted evidence at a minimal cost, the courts should adopt the Hinton per se rule as an exercise of their supervisory power.

The per se rule may not find any foundation in the procedural aspects of Kastigar, but it is consistent with the underlying goal of protecting the privilege against self-incrimination. The courts in both Hinton and Zielezinski recognized that it is improper for prosecutors to engage in the manipulation of the grand jury process that is at issue here. In Zielezinski, the court stated that "[p]rosecutors should avoid permitting grand juries to indict wit-

Hinton, 543 F.2d at 1010.

${ }^{108}$ See id. at 1009 (noting that argument that submitting evidence to second grand jury is too costly and time-consuming is "particularly unconvincing").

${ }^{109}$ An ordinary Kastigar hearing may be held in order to determine whether the prosecution's evidence at the second proceeding was derived from a source wholly independent of the immunized testimony. See Thanasouras, $368 \mathrm{~F}$. Supp. at 534.

110 Hinton, 543 F.2d at 1007; see text at note 107 above. 
nesses who have testified before them under grants of immunity." 11 Both courts realized that there is little justification, economic or otherwise, for this threat to the integrity of the grand jury process. ${ }^{112}$

\section{CoNCLUSION}

The courts should adopt the per se rule of Hinton and prohibit indictment of a witness granted use and derivative use immunity when the indictment is by the same grand jury that heard the compelled testimony. This rule ensures that a witness forced to testify is left in the same position as he would have been had he not been compelled to forego assertion of his fifth amendment privilege against self-incrimination. It also puts an end to an unnecessary and constitutionally suspect practice engaged in by a small number of prosecuting attorneys and thus protects the integrity of the grand jury process.

Charles F. Smith 